\title{
Refund Akibat Pembatalan Tiket Pesawat sebagai Dampak Pandemi Covid-19
}

\section{Rory Jeff Akyuwen}

Fakultas Hukum Universitas Pattimura, Ambon, Indonesia E-mail: rjakyuwen@gmail.com

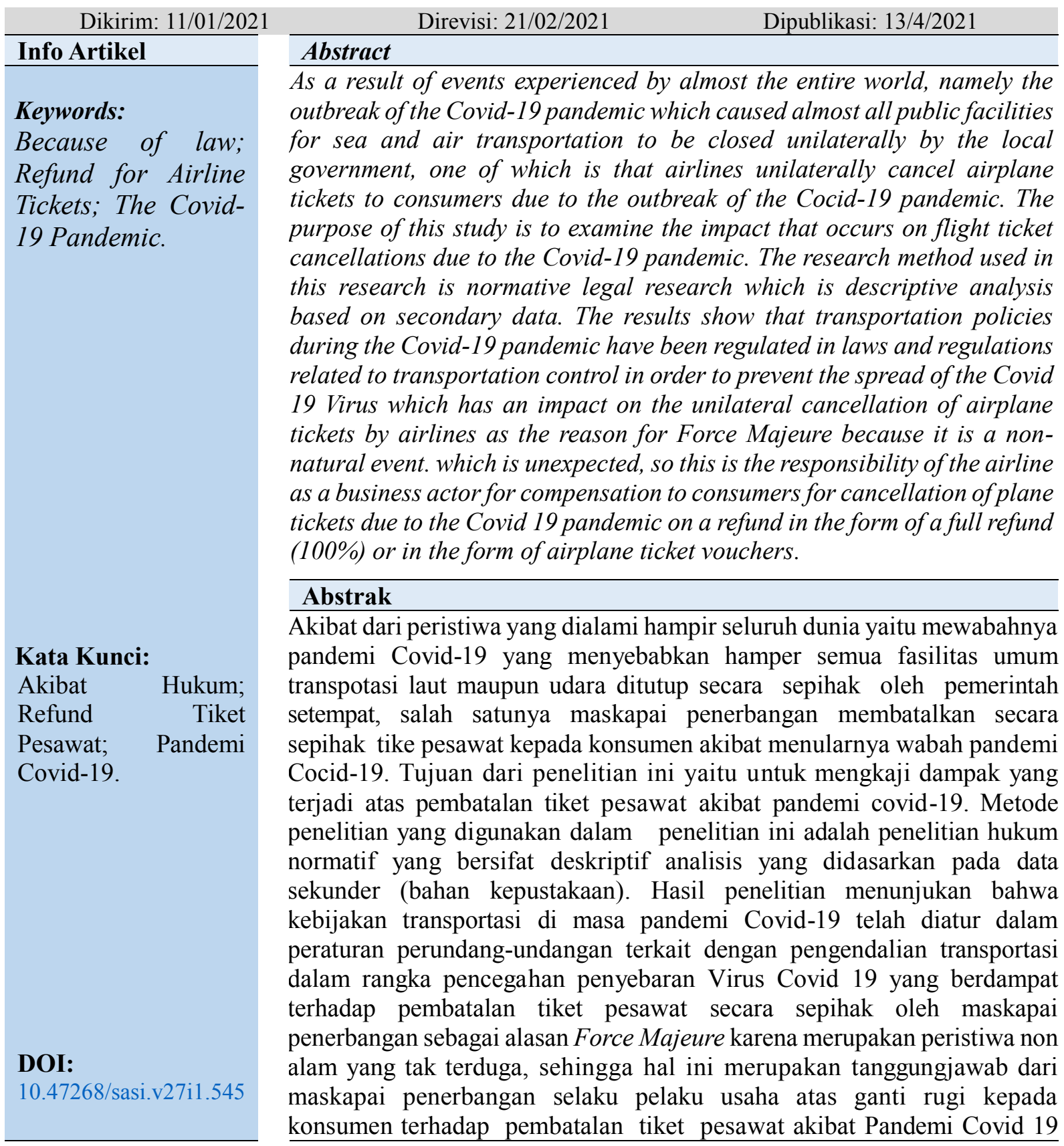




\section{A. PENDAHULUAN}

Pada saat ini perkembangan dalam arus globalisasi dunia dan kerjasama disegala bidang sangat menurun karena terjadinya pandemi di seluruh dunia. Dimana seluruh dunia terkena wabah penyakit menular yang bernama corona atau disebut dengan Covid-19, hal ini menyebabkan penurunan dalam hal ekonomi seluruh dunia termasuk Indonesia yang juga mengalami pandemi Covid-19 yang belum pernah terjadi sebelumnya dan berdampak sangat buruk terhadap perekonomian negara serta masyarakat.

Indonesia masih bergelut melawan virus Corona hingga saat ini, sama dengan negara lain di dunia. Jumlah kasus virus Corona terus bertambah dengan beberapa melaporkan kesembuhan, tapi tak sedikit yang meninggal. Akibat Covid-19 ini terjadi banyaknya tempat wisata, perusahaan, fasilitas umum serta tempat lainnya ditutup oleh pemerintah untuk menghentikan penyebaran penyakit Covid-19 ini dan karena ini diberlakukannya PSBB (Pembatasan Sosial Sekala Bersekala Besar) di seluruh daerah Indonesia.

Dalam Peraturan Pemerintah Pasal 1, yang dimaksud dengan Pembatasan Sosial Berskala Besar (PSBB) adalah pembatasan kegiatan tertentu penduduk dalam suatu wilayah yang diduga terinfeksi Corona Virus Disease 2019 (Covid-19) sedemikian rupa untuk mencegah kemungkinan penyebaran Corona Virus Disease 2019 (Covid-I9) (Peraturan Pemerintah Republik Indonesia Nomor 21 Tahun 2020 Tentang Pembatasan Sosial Berskala Besar Dalam Rangka Percepatan Penanganan Corona Virus Disease 2019 (Covid-19)).

Pasal 4 Ayat (1) (Dilihat dari Peraturan Pemerintah Republik Indonesia Nomor 21 Tahun 2020 Tentang Pembatasan Sosial Berskala Besar Dalam Rangka Percepatan Penanganan Corona Virus Disease 2019 (Covid-19). Pembatasan Sosial Berskala Besar paling sedikit meliputi:
a) Peliburan sekolah dan tempat kerja;
b) Pembatasan kegiatan keagamaan; dan/atau;
c) Pembatasan kegiatan di tempat atau fasilitas umum.

Peraturan terkait pembatasan sosial berskala besar (PSBB) ini mengakibatkan banyaknya pembatasan kegiatan fasilitas umum, fasilitas umum adalah sarana atau prasarana atau perlengkapan atau alat-alat yang disediakan oleh pemerintah untuk kepentingan bersama dalam kegiatan sehari-hari seperti jalan, angkutan umum, rumah sakit, tempat ibadah, taman bermain, dan tempat berolahraga serta yang lainnya.

Corona Virus Disease-19 di Indonesia berdampak buruk bagi perekonomian negara, perbankan, sampai keberlangsungan hidup masyarakat ${ }^{1}$, sehingga banyaknya fasilitas umum yang tutup dan terjadinya penutupan secara sepihak oleh pemerintah, seperti halnya dalam jasa transportasi udara dalam hal ini maskapai penerbangan khususnya di Indonesia membatalkan secara sepihak tiket pesawat kepada pembeli akibat sedang terjadinya pandemi. Padahal telah terjadinya perjanjian jual beli diantara kedua belah pihak, jual-beli (menurut Burgerlijk Wetboek) adalah suatu perjanjian bertimbal- balik dalam mana pihak yang satu (si penjual) berjanji untuk menyerahkan hak milik atas suatu barang, sedang pihak yang lainnya (si pembeli) berjanji untuk membayar harga yang terdiri atas jumlah uang sebagai imbalan dari

1 Taun, T., \& Nugraha, A. (2020). Penerapan Hukum dalam Pemutusan Hubungan Kerja dan Kebijakan Bank Terhadap Debitur yang Terdampak Pandemi Covid-19. Batulis Civil Law Review, 1(1), $24-32$. DOI: https://doi.org/10.47268/ballrev.v1i1.422. h. 24.

$$
\text { 114|SASI Vo1. } 27 \text { No.1, Januari-Maret } 2021
$$


perolehan hak milik tersebut. $^{2}$

Perkataan jual-beli menunjukkan bahwa dari satu pihak perbuatan dinamakan menjual, sedangkan dari pihak yang lain dinamakan membeli. Istilah yang mencakup dua perbuatan yang bertimbal-balik itu adalah sesuai dengan istilah Belanda "koop en verkoop" yang juga mengandung pengertian bahwa pihak yang satu "verkoopt" (menjual) sedang yang lainnya "koopt" (membeli).

Pandemi Covid-19 dalam beberapa bulan terakhir telah melumpuhkan aktivitas dan mobilitas masyarakat hampir di seluruh penjuru dunia, dan penyebarannya yang kian hari kian meluas yang berdampak pada jutaan angka kematian, terpaksa mendorong setiap Negara untuk mengambil kebijakan tegas dalam bentuk pembatasan interaksi fisik antar manusia. Opsi ini kemudian diimplementasikan dengan tingkat keseriusan yang berbeda-beda sesuai dengan kondisi dan kebutuhan masing-masingnya. Ada yang memilih untuk menerapkan pembatasan secara ketat melalui lock down, adapula yang tidak dan seperti diketahui, pemerintah Indonesia sendiri telah menyikapi hal ini dengan menerapkan PSBB, yang sebagai bentuk implementasinya masyarakat didorong untuk melakukan seluruh aktivitas dari rumah dan dihimbau untuk tetap di rumah saja. Lebih lanjut, guna menunjukkan keseriusannya, terhitung sejak tanggal 24 April 2020 hingga 31 Mei 2020, pemerintah juga telah dengan tegas melarang operasional seluruh moda transportasi dan menutup seluruh fasilitas terkait yang dilakukan dalam rangka mudik. Mengingat potensi penularan wabah yang akan semakin meluas akibat tradisi mudik karena mudik akan menjadi momentum terjadinya mobilisasi/pergerakan masa secara besar-besaran.

Pelarangan mudik mengakibatkan pembatalan tiket transportasi laut maupun udara yang telah dibeli oleh konsumen sehingga tidak digunakan. Hal ini apakah konsumen berhak mendapat pengembalian uang tiket (Refund), berapa jumlah dan dalam bentuk apa refund diberikan, ataukah pihak penyelenggara jasa transportasi tidak dapat dimintai pertanggungjawabannya untuk melakukan refund dengan dalil telah terjadi keadaan memaksa (Force Majeure).

\section{B. PEMBAHASAN}

\section{Aspek Hukum Pembatalan Tiket Pesawat Dimasa Pandemi Covid-19}

Dalam hal ini virus corona merupakan termasuk dalam wabah penyakit menular yang terdapat dalam Pasal 1 huruf (a) dan (b) yang terdapat dalam Undang-Undang Nomor 4 Tahun 1984 Tentang Wabah Penyakit Menular, dalam Undang-Undang ini yang dimaksud dengan: Wabah penyakit menular yang selanjutnya disebut wabah adalah kejadian berjangkitnya suatu penyakit menular dalam masyarakat yang jumlah penderitanya meningkat secara nyata melebihi dari pada keadaan yang lazim pada waktu dan daerah tertentu serta dapat menimbulkan malapetaka. Penjelasannya yang dimaksud dengan penyakit menular dalam Undang- Undang ini adalah penyakit menular pada manusia. Karena penyakit dapat berjangkit dari hewan kepada manusia atau sebaliknya ("zoonosa").

Sumber penyakit adalah manusia, hewan, tumbuhan, dan benda-benda yang mengandung dan/atau tercemar bibit penyakit, serta yang dapat menimbulkan wabah. Penjelasannya yang dimaksud dengan bibit penyakit ialah kuman penyakit yang dapat menimbulkan wabah antara lain dapat berupa virus, parasit, bakteri, riketsia dan lain-lain. Upaya Penanggulangan yang terdapat dalam Undang-Undang Nomor 4 Tahun 1984 Tentang Wabah Penyakit Menular yaitu:

Pasal 5:

Upaya penanggulangan wabah meliputi:

${ }^{2}$ Subekti, R. (1995). Aneka Perjanjian. Cetakan Kesepuluh. Bandung: Citra Aditya Bakti. h. 1-2 115 |S A S Vol. 27 No.1, Januari - Maret 2021 
a) penyelidikan epidemiologis;

b) pemeriksaan, pengobatan, perawatan, dan isolasi penderita, termasuk tindakan karantina;

c) pencegahan dan pengebalan;

d) pemusnahan penyebab penyakit;

e) penanganan jenazah akibat wabah;

f) penyuluhan kepada masyarakat; dan

g) upaya penanggulangan lainnya.

Upaya penanggulangan wabah sebagaimana dimaksud dalam ayat (1) dilaksanakan dengan memperhatikan kelestarian lingkungan hidup. Pelaksanaan ketentuan ayat (1) dan ayat (2) diatur dengan Peraturan Pemerintah.

Pasal 6:

Upaya penanggulangan wabah sebagaimana dimaksud dalam Pasal 5 ayat (1) dilakukan dengan mengikutsertakan masyarakat secara aktif.

Tata cara dan syarat-syarat peran serta masyarakat sebagaimana dimaksud dalam ayat (1) diatur dengan Peraturan Pemerintah.

Virus corona ditinjau dari Undang-Undang Nomor 6 Tahun 2018 Tentang Kekarantinaan Kesehatan yaitu:

Pasal 1 ayat (1) dan ayat (2) Dalam Undang-Undang ini yang dimaksud dengan:

Kekarantinaan Kesehatan adalah upaya mencegah dan menangkal keluar atau masuknya penyakit dan/atau faktor risiko kesehatan masyarakat yang berpotensi menimbulkan kedaruratan kesehatan masyarakat.

Kedaruratan Kesehatan Masyarakat adalah kejadian kesehatan masyarakat yang bersifat luar biasa dengan ditandai penyebaran penyakit menular dan/atau kejadian yang disebabkan oleh radiasi nuklir, pencemaran biologi, kontaminasi kimia, bioterorisme, dan pangan yang menimbulkan bahaya kesehatan dan berpotensi menyebar lintas wilayah atau lintas negara.

Pandemi covid-19 ini sudah memasuki tahap dalam kedaruratan kesehatan masyarakat dengan ditandai penyebaran penyakit menular yang telah terjadi diseluruh dunia menyebabkannya terjadinya pandemi dengan banyaknya korban yang terjangkit virus covid-19 serta korban meninggal akibat dari covid-19 tersebut.

Penyelenggaraan Kekarantinaan Kesehatan yang terdapat dalam Undang- Undang Nomor 6 Tahun 2018 Tentang Kekarantinaan Kesehatan yaitu:

Pasal 3

Penyelenggaraan Kekarantinaan Kesehatan bertujuan untuk:

a) melindungi masyarakat dari penyakit dan/atau faktor risiko kesehatan masyarakat yang berpotensi menimbulkan kedaruratan kesehatan masyarakat;

b) mencegah dan menangkal penyakit dan/atau faktor risiko kesehatan masyarakat yang berpotensi menimbulkan kedaruratan kesehatan masyarakat;

c) meningkatkan ketahanan nasional di bidang kesehatan masyarakat; dan

d) memberikan pelindungan dan kepastian hukum bagi masyarakat dan petugas kesehatan.

Hak dan Kewajiban yang diatur dalam Undang-Undang Nomor 6 Tahun 2018 Tentang Kekarantinaan Kesehatan yaitu:

Pasal 7:

116|S A S Vol. 27 No.1, Januari- Maret 2021 
"Setiap Orang mempunyai hak memperoleh perlakuan yang sama dalam penyelenggaraan Kekarantinaan Kesehatan".

Pasal 8:

"Setiap Orang mempunyai hak mendapatkan pelayanan kesehatan dasar sesuai kebutuhan medis, kebutuhan pangan, dan kebutuhan kehidupan sehari-hari lainnya selama Karantina".

Pasal 9:

"Setiap Orang wajib mematuhi penyelenggaraan Kekarantinaan Kesehatan".

Setiap Orang berkewajiban ikut serta dalam penyelenggaraan Kekarantinaan Kesehatan. Dalam upaya pencegahan covid-19 dalam Undang-Undang Kekarantinaan Kesehatan melakukan upaya pencegahan seperti: Pembatasan sosial berskala besar adalah pembatasan kegiatan tertentu penduduk dalam suatu wilayah yang diduga terinfeksi penyakit dan/atau terkontaminasi sedemikian rupa untuk mencegah kemungkinan penyebaran penyakit atau kontaminasi (Terdapat dalam Pasal 1 ayat (11) Undang-Undang Nomor 6 Tahun 2018 Tentang Kekarantinaan Kesehatan). Serta upaya penanggulangan juga terdapat dalam Pasal 1 ayat (8) Undang-Undang Nomor 6 Tahun 2018 Tentang Kekarantinaan Kesehatan yaitu: Karantina Rumah adalah pembatasan penghuni dalam suatu rumah beserta isinya yang diduga terinfeksi penyakit dan/atau terkontaminasi sedemikian rupa untuk mencegah kemungkinan penyebaran penyakit atau kontaminasi.

Virus corona juga ditinjau dari Undang-Undang Nomor 24 Tahun 2007 Tentang Penanggulangan Bencana, karena virus corona termasuk dalam bencana dan bencana non alam yaitu terdapat dalam Pasal 1 ayat (1) dan (3) Undang-Undang Nomor 24 Tahun 2007 Tentang Penanggulangan Bencana, Dalam undang- undang ini yang dimaksud dengan:

Bencana adalah peristiwa atau rangkaian peristiwa yang mengancam dan mengganggu kehidupan dan penghidupan masyarakat yang disebabkan, baik oleh faktor alam dan/atau faktor non alam maupun faktor manusia sehingga mengakibatkan timbulnya korban jiwa manusia, kerusakan lingkungan, kerugian harta benda, dan dampak psikologis.

Bencana non alam adalah bencana yang diakibatkan oleh peristiwa atau rangkaian peristiwa nonalam yang antara lain berupa gagal teknologi, gagal modernisasi, epidemi, dan wabah penyakit.

Hak Dan Kewajiban Masyarakat Undang-Undang Nomor 24 Tahun 2007 Tentang Penanggulangan Bencana yaitu: Bagian Kesatu adalah Hak Masyarakat Pasal 26:

a) Setiap orang berhak:

b) mendapatkan perlindungan sosial dan rasa aman, khususnya bagi kelompok masyarakat rentan bencana;

c) mendapatkan pendidikan, pelatihan, dan keterampilan dalam penyelenggaraan penanggulangan bencana;

d) mendapatkan informasi secara tertulis dan/atau lisan tentang kebijakan penanggulangan bencana;

e) berperan serta dalam perencanaan, pengoperasian, dan pemeliharaan program penyediaan bantuan pelayanan kesehatan termasuk dukungan psikososial;

f) berpartisipasi dalam pengambilan keputusan terhadap kegiatan penanggulangan bencana, khususnya yang berkaitan dengan diri dan komunitasnya; dan

g) melakukan pengawasan sesuai dengan mekanisme yang diatur atas pelaksanaan penanggulangan bencana.

Setiap orang yang terkena bencana berhak mendapatkan bantuan pemenuhan kebutuhan dasar. Setiap orang berhak untuk memperoleh ganti kerugian karena terkena bencana yang 
disebabkan oleh kegagalan konstruksi.

Bagian Kedua adalah Kewajiban Masyarakat

Pasal 27:

Setiap orang berkewajiban:

a) menjaga kehidupan sosial masyarakat yang harmonis, memelihara keseimbangan, keserasian, keselarasan, dan kelestarian fungsi lingkungan hidup;

b) melakukan kegiatan penanggulangan bencana; dan

c) memberikan informasi yang benar kepada publik tentang penanggulangan bencana.

Partisipasi masyarakat menjadi kunci utama untuk pencegahan penyebaran wabah Covid19. Pemerintah dalam pelaksanaan new normal juga menganjurkan masyarakat untuk menerapkan social distancing (pembatasan sosial) dan physical distancing (pembatasan fisik) guna memotong rantai penyebaran virus tersebut. Sebagian masyarakat secara sadar dan kritis mengikuti mekanisme pembatasan sosial, tetapi sebagian lagi belum berpartisipasi. ${ }^{3}$

Penerapan physical distancing yang umum dilakukan yaitu: bekerja dari rumah, belajar di rumah secara online bagi siswa sekolah dan mahasiswa, dan tidak melakukan pertemuan atau acara yang dihadiri orang banyak, seperti konferensi, seminar, rapat, atau pesta pernikahan. Ketika menerapkan physical distancing, seseorang tidak diperkenankan untuk berjabat tangan serta menjaga jarak setidaknya satu (1) meter saat berinteraksi dengan orang lain, terutama dengan orang yang sedang sakit atau berisiko tinggi menderita Covid-19. ${ }^{4}$

Social Distancing atau dapat diartikan sebagai pembatasan jarak sosial, Pembatasan sosial (social distancing) adalah pembatasan kegiatan tertentu penduduk dalam suatu wilayah yang diduga terinfeksi penyakit dan/atau terkontaminasi sedemikian rupa untuk mencegah kemungkinan penyebaran penyakit atau kontaminasi. Mengacu kepada aturan tersebut social distancing bertujuan menekan potensi penyebaran penyakit menular, di mana social distancing bertujuan untuk membatasi kegiatan sosial orang untuk menjauh dari kontak fisik dan keramaian. ${ }^{5}$

Ada beberapa kegiatan social distancing yang bisa kita lakukan sendiri:

a) Self-Isolated, sebisa mungkin berdiam di rumah;

b) Hindari tempat ramai seperti mall, bioskop, transportasi publik, dll;

c) Kurangi berpergian yang tidak penting;

d) Tidak mengadakan kegiatan massal. (>250 orang);

e) Untuk lokasi berisiko tinggi, batalkan pertemuan yang dihadiri $>10$ orang;

f) Jaga jarak 1-3 meter dari orang lain bila memungkinkan;

g) Hindari kontak fisik seperti salaman, high-five, dll;

h) Meeting dengan media online atau telepon.

Pengangkutan atau biasa disebut dengan transportasi merupakan salah satu aspek penting dalam kehidupan. Pengangkutan adalah perjanjian timbal balik antara pengangkut dengan pengirim, dimana pengangkut mengikatkan diri untuk menyelenggarakan pengangkutan barang dan/atau orang dari suatu tempat ke tempat tujuan tertentu dengan selamat, sedangkan

3 Mulyadi, Mohammad. (2020). Partisipasi Masyarakat Dalam Penanganan Penyebaran Covid-19. Info Singkat, Kajian Singkat Terhadap Isu Aktual Dan Strategis. XII (8), 13-18. https://sdip.dpr.go.id/search/detail/category/Info\%20Singkat/id/1058. h. 14.

4 Ibid., h. 15

5 Kresna, Arief \& Ahyar, Juni. (2020). Pengaruh Physical Distancing dan Social Distancing Terhadap Kesehatan dalam Pendekatan Linguistik. Jurnal Syntax Transformation Sosial Sains. 1 (4), 15-19. DOI: https://doi.org/10.46799/\%25J.Vol1.Iss4.42 h. 17. 
pengirim mengikatkan diri untuk membayar uang angkutan. Secara garis besar, moda pengangkutan dapat diklasifikasikan sebagai berikut:

a) Pengangkutan darat melalui jalan raya dan kereta api; ${ }^{6}$

b) Pengangkutan laut; dan

c) Pengangkutan udara

Angkutan sebagai salah satu sarana yang mempunyai peranan penting dalam kehidupan khususnya dalam menjalankan roda perekonomian untuk memenuhi kebutuhan hidup, dimana manusia membutuhkan angkutan sebagai sarana yang tak terpisahkan dari mata rantai perekonomian. Namun, beberapa bulan terakhir dunia sedang menghadapi krisis pandemi Corona virus Disease 2019 atau biasa disebut dengan Covid-19.

Pandemi Covid-19 telah menyebar dengan cepat ke seluruh dunia yang menyebabkan berhentinya rutinitas harian dan dalam beberapa kasus ekstrim, Covid-19 telah merenggut jutaan nyawa. Seluruh dunia berada dalam mode krisis, tidak terkecuali Indonesia. Covid-19 pertama dilaporkan di Indonesia pada tanggal 2 Maret 2020 sejumlah dua kasus. ${ }^{7}$ Data 8 Juni 2020 menunjukkan kasus yang terkonfirmasi berjumlah 32.033 kasus dan 1.883 kasus kematian. ${ }^{8}$ Dalam hal ini, pemerintah Indonesia telah menetapkan wabah Covid-19 sebagai bencana nasional. Dampak Covid-19 telah memengaruhi banyak sektor dalam kegiatan seharihari, salah satunya dalam sektor transportasi. Dampak yang sangat besar dalam sektor transportasi menyebabkan terjadinya penurunan aktivitas di transportasi darat, laut, dan bandar udara. Pemerintah juga membatasi mobilisasi, baik orang maupun barang antar daerah di dalam negeri. Akibatnya, banyak proses produksi berhenti atau menurun yang berimbas terhadap aktivitas ekonomi secara lokal, domestik, regional, dan global.

Merespon pandemi Corona Virus Disease 2019 (Covid-19), pemerintah Indonesia mulai menerapkan pembatasan dengan kebijakan social distancing (jaga jarak sosial, menghindari kerumunan), lalu physical distancing (jaga jarak antar orang minimal 1,8 meter) sejak awal Maret 2020. Kebijakan itu telah menurunkan secara drastis aktivitas dan pergerakan orang di Jabodetabek dan kota-kota besar. Hal ini dapat dilihat dari menurunnya jumlah penumpang pada berbagai sarana transportasi mulai pesawat terbang, kereta api, kereta api komuter, bus dan busway, angkot, taksi, taksi online, bajaj, hingga ojek dan ojek online (ojol). ${ }^{9}$

Dalam rangka mencegah Covid-19 semakin menyebar, pemerintah menerapkan beberapa kebijakan untuk termasuk menjaga jarak fisik, seperti Pembatasan Sosial Berskala Besar (PSBB). Pembatasan Sosial Berskala Besar adalah pembatasan kegiatan tertentu penduduk dalam suatu wilayah yang diduga terinfeksi Corona Virus Disease 2019 (COVID-19) sedemikian rupa untuk mencegah kemungkinan penyebaran Corona Virus Disease 2019 (COVID-I9). ${ }^{54}$

Kebijakan transportasi dimasa pandemi Covid-19, Indonesia telah mengeluarkan dua Permenhub yaitu Peraturan Menteri Perhubungan Nomor 18 Tahun 2020 tentang Pengendalian Transportasi Dalam Rangka Pencegahan Penyebaran Virus COVID 19 tanggal 09 April 2020 dan Peraturan Menteri Perhubungan Nomor 25 Tahun 2020 tentang Pengendalian Transportasi yang berlaku sejak 24 April 2020.

${ }^{6}$ Nadine, Ainaya \& Imtiyaz, Z. Z. (2020). Analisis Upaya Pemerintah Dalam Menangani Mudik Melalui Peraturan Menteri Perhubungan Nomor 25 Tahun 2020 Pada Masa Covid-19. Media Iuris, 3 (3), $277-298$. DOI: http://dx.doi.org/10.20473/mi.v3i3.20674h. 278

7 Ibid

8 Kementerian Kesehatan Republik Indonesia, Info Infeksi Emerging Corona Virus (Infeksi Emerging 2020) (Kementerian Kesehatan Republik Indonesia, 2020) https://covid19.kemkes.go.id/ category/situasi-infeksi-emerging/info-corona- virus/\#.XwsRcSgzbIU, diakses tanggal 20 Desember 2020.

9 Hadiwardoyo, Wibowo. (2020). Pusat Inkubator Bisnis dan Kewirausahaan Universitas Muhammadiyah Jakarta Baskara, Journal of Business and Entrepreneurship. 2 (2), 83-92. DOI: 10.24853/baskara.2.2.83-92. h. 83. 
Beberapa kebijakan yang dikeluarkan oleh pemerintah terkait transportasi di Indonesia sering berubah-ubah. Semua perubahan berlangsung dalam waktu singkat di tengah pandemi Covid-19 ini membuat masyarakat bingung untuk menentukan sikap, tidak heran banyak ditemukan kasus di lapangan bahwa dengan adanya kebijakan berupa Peraturan Menteri Perhubungan dalam rangka memotong penyebaran Covid-19 tidak mengurungkan niat masyarakat untuk tetap bepergian dari satu tempat ke tempat yang lainnya.

Penerapan Pembatasan Sosial Berskala Besar (PSBB) dan wilayah zona merah Covid-19. Seperti yang diketahui bahwa Covid-19 dapat menyebar melalui droplet, dan penularan terjadi melalui kontak jarak dekat. Dikarenakan penularannya yang mudah ini, masyarakat dianjurkan untuk menjaga jarak fisik atau physical distancing saat berada di tempat umum. Hal inilah yang menjadi salah satu dasar pertimbangan pemerintah membatasi penggunaan transportai umum.

Salah satu yang terdampak sarana transportasi udara (maskapai penerbangan), yaitu dengan pembatalan sejumlah perjalanan transpotasi udara. Maskapai penerbangan mencatat setidaknya ada ratusan ribu tiket yang dibatalkan dengan berbagai tujuan baik dalam negeri maupun luar negeri. Pembatalan tiket pesawat saat pandemi Covid 19, merupakan bentuk pengendalian lalu lintas sarana transportasi selama pandemi. Sebagaimana disebutkan dalam Pasal 1 ayat (1) Peraturan Menteri Perhubungan Nomor 25 Tahun 2020 tentang Pengendalian Transportasi menyatakan: "Pengendalian transportasi dalam rangka pencegahan penyebaran Corona Virus Disease 2019 (COVID-19) adalah pengendalian dalam bentuk pembatasan moda transportasi".

Pasal 2 Peraturan Menteri Perhubungan No. 25 tahun 2020 menyebutkan Pengendalian Transportasi Dalam Rangka Pencegahan Penyebaran Corona Virus Disease 2019 (COVID-19) dilakukan melalui:

a) pengendalian transportasi untuk seluruh wilayah;

b) pengendalian transportasi pada wilayah yang ditetapkan sebagai Pembatasan Sosial Berskala Besar; dan

c) pengendalian transportasi untuk kegiatan mudik tahun 2020.

Pengendalian transportasi ini dilakukan termasuk pada maskapai penerbangan yang melakukan pembatalan tiket pesawat pada masa awal pandemi Covid 19 ini. Kebijakan ini merupakan suatu keharusan bagi maskapai penerbangan untuk dilakukan pada masa-masa darurat wabah pandemi Covid 19. Keberhasilan pemerintah dalam hal melarang masyarakatnya untuk berpergian dapat ditinjau dari produk hukum berupa Peraturan Menteri Perhubungan No. 25 tahun 2020. Peraturan tersebut diharapkan mampu untuk menciptakan keadaan yang dikehendaki oleh hukum, hal ini berkaitan dengan kemampuan pemerintah dalam membatasi penyebaran Covid-19 dengan pemberian sanksi kepada masyarakat yang melanggar sebagai sebuah bentuk penegakan hukum.

Secara umum tujuan pembentukan perundang-undangan adalah mengatur dan menata kehidupan dalam suatu negara supaya masyarakat yang diatur oleh hukum itu memperoleh kepastian, kemanfaatan dan keadilan di dalam kehidupan bernegara dan bermasyarakat. ${ }^{10}$ Peraturan perundang-undangan sebagai hukum yang tertulis yang diberi bentuk sejak awal diharapkan bahwa dalam pelaksanaannya akan memberikan kepastian hukum. Disadari bahwa suatu hukum tertulis mengandung banyak kelemahan, tetapi juga memiliki kelebihan dibanding dengan hukum yang tidak tertulis. Peranan peraturan perundang-undangan semakin penting sebagai tuntutan asas legalitas sebagai salah satu ciri negara hukum. Dalam negara kesejahteraan modern, tatkala menyusun suatu rencana, peraturan perundang-undangan

10 Indrati, Maria Farida S. (2007). Ilmu Perundang-Undangan: Proses Dan Teknik Pembentukannya, Yogyakarta: Kanisius, 2007

$$
\text { 120|SASI Vo1. } 27 \text { No.1, Januari-Maret } 2021
$$


semakin penting baik sebagai kerangka rencana itu sendiri, maupun sebagai instrument pemandu dalam melaksanakan suatu rencana ${ }^{11}$ Sehingga, menjadi penting adanya suatu peraturan perundang- undangan dalam negara hukum.

Mengenai hierarki peraturan perundang-undangan, hal ini diatur dalam Pasal 7 ayat (1) Undang-Undang Nomor 12 Tahun 2011 tentang Pembentukan Peraturan Perundang-Undangan. Disamping jenis peraturan perundang-undangan yang disebutkan dalam Pasal 7 ayat (1) UU No. 12/2011 juga dikenal jenis peraturan perundang-undangan lainnya, baik yang dikeluarkan oleh badan/lembaga/pejabat pemerintah pusat seperti; Keputusan Presiden (Keppres), Peraturan Menteri (Permen), dan Keputusan Menteri (Kepmen), maupun peraturan perundangundangan yang dikeluarkan oleh pemerintah daerah, seperti: Peraturan Gubernur, Peraturan Bupati, Peraturan Walikota, Keputusan Gubernur, Keputusan Bupati, dan Keputusan Walikota. ${ }^{12}$

Mengenai Peraturan Menteri No. 25/2020, dimana terhadap Peraturan Menteri tidak disebutkan secara eksplisit dalam hierarki peraturan perundang- undangan yang tercantum di dalam Pasal 7 ayat (1) UU No. 12/2011. Apabila dilakukan penafsiran secara sistematis, kedudukan Peraturan Menteri dapat dilihat dalam Pasal 8 ayat (2) UU No. 12/2011. Pasal 8 ayat (2) UU No. 12/2011 menyatakan bahwa Peraturan Perundang-undangan sebagaimana dimaksud pada ayat (1) diakui keberadaannya dan mempunyai kekuatan hukum mengikat sepanjang diperintahkan oleh Peraturan Perundang-undangan yang lebih tinggi atau dibentuk berdasarkan kewenangan.

Dalam Pasal tersebut memiliki makna bahwa kedudukan Peraturan Menteri yang dibentuk setelah berlakunya UU No. 12/2011, baik yang dibentuk atas dasar perintah peraturan perundang-undangan yang lebih tinggi maupun yang dibentuk atas dasar kewenangan di bidang urusan pemerintahan tertentu yang ada pada menteri, berkualifikasi sebagai peraturan perundang-undangan. Sehingga Permenhub tetap memiliki kekuatan hukum mengikat.

Adanya pandemi Covid-19 yang terus meluas di berbagai belahan dunia termasuk Indonesia membawa perubahan signifikan terhadap kehidupan. Dengan keadaan seperti ini, maka diperlukan adanya penanggulangan dalam berbagai aspek. Pemerintah pusat dituntut untuk sesegera mungkin menangani pandemi Covid-19 ini, sehingga diterbitkanlah pengaturanpengaturan mengenai protokol kesehatan di berbagai macam sektor termasuk sektor transportasi dalam rangka pengawasan sebagai langkah preventif. Transportasi merupakan hal penting sebagai sarana untuk melakukan kegiatan aktivitas sehari-hari untuk berpindah dari suatu tempat ke tempat tujuan dengan selamat. Hal ini sudah barang tentu menjadi kewenangan pemerintah dalam membentuk peraturan dalam rangka peran pemerintah melakukan pengawasan untuk menanggulangi penyebaran Covid-19 di sektor transportasi khususnya oleh Kementerian Perhubungan, maka, dibentuklah Peraturan Menteri Perhubungan (Permenhub) No. 25/2020. Permenhub ini merupakan salah satu upaya pemerintah dalam membatasi sarana transportasi agar mencegah penyebaran covid-19, dalam hal ini khususnya kereta api.

Setiap peraturan tentu memuat suatu bentuk aturan yang bersifat preventif dan bersifat represif. Pengawasan merupakan langkah preventif untuk memaksakan kepatuhan, sedangkan penerapan sanksi merupakan langkah represif untuk memaksakan kepatuhan. Pengawasan yang merupakan langkah preventif tersebut berupa dibuatnya peraturan perundang-undangan dalam rangka mencegah penyebaran virus sesuai dengan protokol kesehatan salah satunya Permenhub No. 25 Tahun 2020. Sedangkan, sanksi merupakan langkah represif sebagai bentuk upaya penegakan hukum dan merupakan bagian penutup yang penting di dalam hukum.

Pada prinsipnya kegiatan pengangkutan udara merupakan hubungan hukum yang bersifat

11 Jalaluddin. (2011). Hakikat dan Fungsi Peraturan Perundang-Undangan Sebagai Batu Uji Kritis

Terhadap Gagasan Pembentukan Perda Yang Baik. Atualita, 6 (3), 1-19. http://jurnal.untad.ac.id/jurnal/index.php/AKTUALITA/article/view/2481.

12 Nadine, Ainaya \& Imtiyaz, Z. Z. Op.Cit, h. 280.

121|S A S Vol. 27 No.1, Januari- Maret 2021 
perdata akan tetapi mengingat transportasi udara telah menjadi kebutuhan masyarakat secara luas maka diperlukan campur tangan pemerintah dalam kegiatan pangangkutan udara yaitu menentukan kebijakan-kebijakan atau regulasi yang berhubungan dengan kegiatan pengangkutan udara sehingga kepentingan konsumen pengguna jasa transportasi udara terlindungi, ${ }^{13}$ sebab dalam hukum perlindungan konsumen bertujuan secara langsung untuk meningkatkan martabat dan kesadaran konsumen, dimana secara tidak langsung hukum ini juga akan mendorong produsen untuk melakukan usaha dengan penuh tanggung jawab ${ }^{14}$.

\section{Pengembalian Uang (Refund) Akibat Pembatalan Tiket Pesawat sebagai alasan Force Majeure Dimasa Pandemi Cocid-19}

Pandemi Covid-19 telah membatalkan aktivitas dan mobilitas masyarakat hampir di seluruh penjuru bumi. Kenyataannya bahwa hingga saat ini belum ditemukan obat yang tepat untuk mengatasinya, sedangkan penyebarannya dan penularan yang semakin hari semakin meluas yang berakibat peningkatan angka kematian akibat covid-19, terpaksa mendesak setiap Negara untuk mengambil kebijakan tegas dalam bentuk pembatasan interaksi fisik antar manusia. Opsi ini kemudian diimplementasikan dengan tingkat keseriusan yang berbeda-beda sesuai dengan kondisi dan kebutuhan masing-masingnya. Ada yang memilih untuk menerapkan pembatasan secara ketat melalui lock down, adapula yang tidak dan seperti diketahui, pemerintah Indonesia sendiri telah menyikapi hal ini dengan menerapkan PSBB, yang sebagai bentuk implementasinya masyarakat didorong untuk melakukan seluruh aktivitas dari rumah dan dihimbau untuk tetap di rumah saja. Lebih lanjut, guna menunjukkan keseriusannya, terhitung sejak tanggal 24 April 2020 hingga 31 Mei 2020, pemerintah juga telah dengan tegas melarang operasional seluruh moda transportasi dan menutup seluruh fasilitas terkait yang dilakukan dalam rangka mudik. Mengingat potensi penularan wabah yang akan semakin meluas akibat tradisi mudik karena mudik akan menjadi momentum terjadinya mobilisasi/pergerakan masa secara besar-besaran. Berkaitan dengan pelarangan mudik tersebut, berdampat terhadap pembatalan tiket transportasi khsususnya tiket pesawat yang telah dibeli oleh masyarakat (Konsumen), sehingga konsumen berhak mendapat pengembalian uang tiket (Refund).

Penumpang yang menggunakan jasa angkutan udara tidak hanya dirugikan dalam hal waktu tapi dapat pula secara materil akibat pembatalan penerbangan. ${ }^{15}$ Refund atau pengembalian dana tiket penumpang pesawat pada masa pandemi masih menjadi diskusi dalam mengambil kebijakan dari sisi maskapai penerbangan, travel agent, dan penumpang, hal ini disebabkan karena banyaknya kasus refund tiket di Indonesia, khususnya penerbangan sehingga menimbulkan efek berkepanjangan bagi ketiga pihak (masakapai penerbangan, travel agent dan penumpang). Menurut pengamat penerbangan Jaringan Penerbangan Indonesia Gerry Soejatman, memprediksi kondisi refund tiket pesawat dengan membandingkannya sebelum dan sesudah pandemi. Dalam kondisi normal, yang di-refund itu mungkin satu persen dari tiket yang beredar," Sementara itu, Sekretaris Jenderal Astindo, Pauline Suharno menerangkan bagaimana kondisi travel agent saat ini dapat bertahan hidup karena yang paling terdampak untuk industri pariwisata saat ini, karena beragam tantangan harus dihadapi yaitu harus mengurus refund karena tidak ada penjualan. ${ }^{16}$

Membahas hak dan kewajiban antara konsumen dan pelaku usaha jasa transportasi udara,

13 Widaja, Gunawan \& Yani, Ahmad. (2003). Hukum Tentang Perlindungan Konsumen, Jakarta: Gramedia Pustaka Utama. h. ix

14 Sidabalok, Janus. (2006). Hukum Perlindungan Konsumen di Indonesia. Bandung: Citra Aditya Bakti, h. 71 .

15 Setiadi, W. T. \& Nurmawati, Made. Tanggung Jawab Perusahaan Angkutan Udara dalam Pembatalan Tiket Penerbangan. Kertha Semaya: Journal Ilmu Hukum, $6 \quad$ (10), 1-15. https://ocs.unud.ac.id/index.php/kerthasemaya/article/view/40719. h. 1.

16 Aditya, Nicholas Ryan. Seberapa Besar Kasus Refund Tiket Penerbangan pada Masa Pandemi. https://travel.kompas.com/read/2020/06/19/194000427/seberapa-besar-kasus-refund-tiket-penerbangan-padamasa-pandemi?page $=$ all.

$$
\text { 122|SASI Vo1. } 27 \text { No.1, Januari-Maret } 2021
$$


perlu dilihat hubungan hukumnya terlebih dahulu dan merujuk pada Pasal 1457 KUHPerdata, hubungan hukum yang terbentuk di antara para pihak terjadi karena penutupan perjanjian bertimbal balik dalam bentuk jual beli tiket, dimana Maskapai mengikatkan dirinya untuk menyerahkan suatu kebendaan (dalam hal ini jasa untuk mengangkut konsumen melalui moda angkutannya) dan konsumen mengikatkan diri untuk membayar harga yang dijanjikan. Dalam praktek, pembayaran tiket secara penuh selalu dipersyaratkan untuk dilakukan di depan sebelum tiket diterbitkan oleh Maskapai. Dengan demikian, dalam tahapan pembelian, konsumen telah memenuhi prestasinya untuk melakukan kewajiban pembayaran yang di sisi lain menimbulkan kewajiban secara berimbang bagi Maskapai untuk melaksanakan pengangkutan sesuai dengan jadwal yang disepakati di dalam tiket. Dari hubungan ini, dapat disimpulkan bahwa, konsumen bertindak sebagai Kreditur (pihak yang berhak atas pemenuhan suatu prestasi) dan Maskapai sebagai Debitur (pihak yang wajib melakukan kontraprestasi). ${ }^{17}$ Sebelum terjadinya keadaan-keadaan yang menyebabkan tidak dapat dilaksanakan prestasi tersebut, seharusnya ada langkah-langkah pencegahan yang perlu dilakukan oleh setiap angkutan udara agar pada saat terjadinya kendala tersebut para konsumen yang telah membeli tiket tidak merasa kecewa dan dirugikan akibat pelayanan yang buruk dari pihak angkutan udara. ${ }^{18}$ Berdasarkan Privity of Contract Theory, pelaku usaha mempunyai kewajiban untuk melindungi konsumen, akan tetapi hal itu baru dapat dilakukan apabila diantara mereka telah terjalin suatu hubungan kontraktual. ${ }^{19}$

Perjanjian dalam keadaan wabah Covid-19 sangat berpengaruh terhadap pelaksanaan perjanjian yang ditetapkan dan disepakati oleh para pihak, sebab perjanjian tersebut mengikat para pihak, sehingga para pihak tunduk pada isi perjanjian ${ }^{20}$. KUHPerdata sesuai dengan Pasal 1245 dikenal suatu kondisi yang disebut sebagai keadaan memaksa (Force Majeure) atau overmacht dalam bahasa Belanda, dimana Kreditur dapat dibebaskan dari kewajibannya untuk melakukan prestasi tanpa disertai kewajiban untuk melakukan penggantian biaya, rugi dan bunga dan kondisi ini akan menjadi alasan pembenar dan pemaaf. Secara struktur, ketentuan ini termuat dalam Buku III KUHPerdata yang menganut sistem terbuka, yakni, implementasinya tidak mutlak, dapat disimpangi para pihak dan merupakan pelengkap dalam praktek. Terdapat elemen Force Majeure yang disebakan karena tidak memenuhi prestasi; Ada sebab yang terletak di luar kesalahan debitur; dan Faktor penyebab itu tidak terduga sebelumnya dan tidak dapat dipertanggungjawabkan kepada debitur.

Merujuk pada elemen Force Majeure tersebut, maka kasus pembatalan tiket pesawat oleh Maskapai di tengah pandemi Covid-19 sebagai implementasi kebijakan pemerintah, memenuhi karakteristik Force Majeure. Mengingat kebijakan ini dan terjadinya pandemi tidak terduga sebelumnya. Meskipun demikian, pandangan apakah pandemi Covid -19 merupakan Force Majeure atau bukan, hingga saat ini masih menimbulkan perdebatan di kalangan praktisi dan akademisi meskipun Presiden telah menetapkan COVID-19 sebagai bencana nasional non alam. Jika pandemi Covid -19 dipandang sebagai Force Majeure, apakah benar Maskapai tidak bisa dimintai pertanggung jawaban untuk mengganti biaya, kerugian dan bunga sesuai dengan Pasal 1245 KUHPerdata? Mengenai hal ini, pemerintah telah mengatur kebijakan tersendiri berdasarkan Permenhub No. PM 185 Tahun 2015 tentang Standar Pelayanan Penumpang Kelas Ekonomi Angkutan Udara Niaga Berjadwal Dalam Negeri ("PM 185/2015"). Merujuk pada PM 185/2015, terjadinya suatu Force Majeure dalam aktivitas penerbangan, berdampak pada pembatalan tiket. Konsekuensi ini sangat masuk akal, karena adanya Force Majeure secara langsung tentu akan menggagalkan pengangkutan sesuai dengan jadwal yang

17 Nasution, Mulyana Raifa. Refund Tiket Pesawat dalam bentuk Voucher Akibat Pandemi Covid-19 dalam Perspektif Hukum Perdata. https://kliklegal.com/refund-tiket-pesawat-dalam-bentuk-voucher-akibat-pandemicovid-19-dalam-perspektif-hukum-perdata/

18 Nasution, A Z. (2002). Pengantar Hukum Perlindungan Konsumen, Jakarta: Daya Widya. h. 119.

19 Shidarta. (2006). Hukum Perlindungan Konsumen Indonesia, Jakarta: Grasindo, h. 62.

${ }^{20}$ Kunarso, K., \& Sumaryanto, A.D. (2020). Eksistensi Perjanjian Ditengah Pandemi Covid-19. Batulis Civil Law Review, 1(1), 33-46. DOI: https://doi.org/10.47268/ballrev.v1i1.423. h. 33.

$$
\text { 123|SASI Vo1. } 27 \text { No.1, Januari-Maret } 2021
$$


ditentukan (kontraprestasi Maskapai tidak bisa dipenuhi). Atas kondisi ini, berdasarkan Pasal 10 ayat (1) PM 185/2015 telah ditegaskan bahwa Maskapai wajib mengembalikan biaya jasa angkutan udara yang telah dibayarkan oleh calon penumpang (refund tiket). Lebih lanjut ayat (3) Pasal ini mengatur bahwa jumlah Refund yang harus diberikan, dengan ketentuan: ${ }^{21}$

a) Untuk penerbangan dengan kelompok pelayanan full service, dilakukan pemotongan biaya administrasi sebesar $20 \%$;

b) Untuk penerbangan dengan kelompok pelayanan medium service, dilakukan pemotongan biaya administrasi sebesar $15 \%$; dan

c) Untuk penerbangan dengan kelompok pelayanan no-frills, dilakukan pemotongan biaya administrasi sebesar $10 \%$."

Selain Refund atas biaya jasa angkutan, Refund juga harus diberikan atas Passenger Service Charge (PSC). Mengenai jadwal pengembalian, selanjutnya ditemukan dalam Pasal 10 ayat (5) PM 185/2015, selambat-lambatnya yaitu: a) 15 hari kerja sejak pengajuan dalam hal tiket dibeli secara tunai; dan (b) 30 hari kerja sejak pengajuan dalam hal pembelian dengan kartu kredit. Sebagai alternatif refund tiket pesawat dalam bentuk voucher yang bisa digunakan untuk pemesanan kembali tiket maskapai untuk jadwal dan rute sesuai dengan pilihan Konsumen. Pemerintah pun telah berpendapat bahwa alternatif ini tidak menyalahi peraturan perundang-undangan yang berlaku. Sehingga konsumen tidak mempunyai pilihan lain selain untuk menggunakan voucher yang ada mengingat pada akhirnya apabila voucher tidak digunakan akan dengan sendirinya menggugurkan hak Konsumen atas untuk pemenuhan kontraprestasi Maskapai pasca berakhirnya jangka waktu keberlakukan voucher.

\section{PE N T U P}

Kebijakan pemerintah terkait dengan pencegahan Covid-19 semakin menyebar, maka menerapkan beberapa kebijakan yaitu menjaga jarak fisik, seperti Pembatasan Sosial Berskala Besar (PSBB) untuk mencegah kemungkinan penyebaran Corona Virus Disease 2019. Tanggung jawab maskapai penerbangan selaku pelaku usaha atas pembatalan tiket pesawat akibat wabah pandemi Covid 19 yaitu dalam bentuk memberikan kompensasi ganti rugi pengembalian uang tiket $100 \%$ dan voucher kepada konsumen (penumpang) atas biaya tiket pesawat yang telah dibatalkan.

\section{DAFTAR PUSTAKA}

\section{Jurnal}

[1] Hadiwardoyo, Wibowo. (2020). Pusat Inkubator Bisnis dan Kewirausahaan Universitas Muhammadiyah Jakarta Baskara, Journal of Business and Entrepreneurship. 2 (2), 83-92. DOI: 10.24853/baskara.2.2.83-92.

[2] Kunarso, K., \& Sumaryanto, A.D. (2020). Eksistensi Perjanjian Ditengah Pandemi Covid19. Batulis Civil Law Review, 1(1), 33-46. DOI: https://doi.org/10.47268/ballrev.v1i1.423.

[3] Jalaluddin. (2011). Hakikat dan Fungsi Peraturan Perundang-Undangan Sebagai Batu Uji Kritis Terhadap Gagasan Pembentukan Perda Yang Baik. Atualita, 6 (3), 1-19. http://jurnal.untad.ac.id/jurnal/index.php/AKTUALITA/article/view/2481.

[4] Kresna, Arief \& Ahyar, Juni. (2020). Pengaruh Physical Distancing dan Social Distancing Terhadap Kesehatan dalam Pendekatan Linguistik. Jurnal Syntax Transformation Sosial Sains. 1

DOI: https://doi.org/10.46799/\%25J.Vol1.Iss4.42.

[5] Mulyadi, Mohammad. (2020). Partisipasi Masyarakat Dalam Penanganan Penyebaran

21 Ibid

124|SASI Vo1.27 No.1, Januari-Maret 2021 
Covid-19. Info Singkat, Kajian Singkat Terhadap Isu Aktual Dan Strategis. XII (8), 13-18. https://sdip.dpr.go.id/search/detail/category/Info\%20Singkat/id/1058.

[6] Nadine, Ainaya \& Imtiyaz, Z. Z. (2020). Analisis Upaya Pemerintah Dalam Menangani Mudik Melalui Peraturan Menteri Perhubungan Nomor 25 Tahun 2020 Pada Masa Covid19. Media Iuris, 3 (3), 277-298. DOI: http://dx.doi.org/10.20473/mi.v3i3.20674h.

[7] Setiadi, W. T. \& Nurmawati, Made. Tanggung Jawab Perusahaan Angkutan Udara Dalam Pembatalan Tiket Penerbangan. Kertha Semaya: Journal Ilmu Hukum, 6 (10), 1-15. https://ocs.unud.ac.id/index.php/kerthasemaya/article/view/40719.

[8] Taun, T., \& Nugraha, A. (2020). Penerapan Hukum dalam Pemutusan Hubungan Kerja dan Kebijakan Bank Terhadap Debitur yang Terdampak Pandemi Covid-19. Batulis Civil Law Review, 1(1), 24-32. DOI: https://doi.org/10.47268/ballrev.v1i1.422.

[9] Wibowo Hadiwardoyo, Pusat Inkubator Bisnis dan Kewirausahaan Universitas Muhammadiyah Jakarta Baskara: Journal of Business and Entrepreneurship Volume 2 No. 2 April 2020.

\section{Buku}

[10] Indrati, Maria Farida S. (2007). Ilmu Perundang-Undangan: Proses Dan Teknik Pembentukannya, Yogyakarta: Kanisius.

[11] Nasution, A. Z. (2002). Pengantar Hukum Perlindungan Konsumen, Jakarta: Daya Widya. [12] Subekti, R. (1995). Aneka Perjanjian. Cetakan Kesepuluh. Bandung: Citra Aditya Bakti. [13] Sidabalok, Janus. (2006). Hukum Perlindungan Konsumen di Indonesia. Bandung: Citra Aditya Bakti.

[14] Shidarta. (2006). Hukum Perlindungan Konsumen Indonesia, Jakarta: Grasindo.

[15] Widaja, Gunawan \& Yani, Ahmad. (2003). Hukum Tentang Perlindungan Konsumen, Jakarta: Gramedia Pustaka Utama.

\section{Online/World Wide Web}

[16] Aditya, Nicholas Ryan. Seberapa Besar Kasus Refund Tiket Penerbangan pada Masa Pandemi. https://travel.kompas.com/read/2020/06/19/194000427/seberapa-besar-kasusrefund-tiket-penerbangan-pada-masa-pandemi?page $=$ all.

[17] Kementerian Kesehatan Republik Indonesia, Info Infeksi Emerging Corona Virus (Infeksi Emerging 2020) (Kementerian Kesehatan Republik Indonesia, 2020) https://covid19.kemkes.go.id/ category/situasi-infeksi-emerging/info-corona- virus/\#.XwsRcSgzbIU, diakses tanggal 20 Desember 2020.

[18] Nasution, Mulyana Raifa. Refund Tiket Pesawat dalam bentuk Voucher Akibat Pandemi Covid-19 dalam Perspektif Hukum Perdata. https://kliklegal.com/refund-tiket-pesawatdalam-bentuk-voucher-akibat-pandemi-covid-19-dalam-perspektif-hukum-perdata. 